\title{
FIESTA BARROCA (1992): LA CIUDAD COMO \\ ESCENARIO. UNA ESCENOGRAFÍA DE ANDREA \\ D'ODORICO PARA LA COMPAÑÍA NACIONAL \\ DE TEATRO CLÁSICO'
}

\section{FIESTA BARROCA (1992): THE CITY AS A STAGE. A SCENOGRAPHY BY ANDREA D'ODORICO FOR THE NATIONAL CLASSICAL THEATRE COMPANY}

\author{
Olivia NIETO YUSTA \\ Grupo de investigación del SELITEN@T \\ olivianieto.nieto@gmail.com
}

Resumen: El presente trabajo estudia la escenografía diseñada por Andrea D'Odorico para Fiesta barroca (1992), una obra de la Compañía Nacional de Teatro Clásico dirigida por Miguel Narros. Este espectáculo recrea el espíritu festivo del siglo XVII. La escenografía se ha inspirado en el teatro del Siglo de Oro, el carnaval y en la iconografía de distintos periodos artísticos (el Renacimiento, el Barroco y la Antigüedad Clásica). Se trata de uno de los más bellos y complejos diseños realizados por Andrea D'Odorico.

Palabras clave: Andrea D'Odorico. Miguel Narros. Compañía Nacional de Teatro Clásico. Fiesta barroca (1992). Escenografía.

Abstract: The present article studies the scenography designed by Andrea d'Odorico for Fiesta barroca (1992), a play by the National Classical Theatre Company directed by Miguel Narros. This performance revives the festive spirit of the 17th century. The scenography is inspired by the Spanish Golden Age Drama, the carnival and in the iconography of different periods of art history (Renaissance, Baroque and Classical Antiquity). This is one of the most beautiful and complex designs made by Andrea D'Odorico.

Key words: Andrea D'Odorico. Miguel Narros. The National Classical Theatre Company. Fiesta barroca (1992). Scenography.

1 Este trabajo forma parte de mi tesis doctoral Calderón de la Barca en la Compañía Nacional de Teatro Clásico (1986-2013) y la función dramatúrgica de la escenografía, dirigida por el profesor José Romera Castillo, perteneciente al Doctorado en Literatura y Teatros Españoles e Hispanoamericanos en el Contexto Europeo de la Universidad Nacional de Educación a Distancia (U.N.E.D.), y que además se inserta dentro de las actividades llevadas a cabo en el SELITEN@T, Centro de Investigación de Semiótica Literaria, Teatral y Nuevas Tecnologías, dirigido por el profesor Romera Castillo, que pueden verse en http://www.uned.es/ centro-investigacion-SELITEN@T [01/12/2016]. 


\section{INTRODUCCIÓN}

El arquitecto, escenógrafo, figurinista y productor teatral Andrea D'Odorico falleció en diciembre de 2014 dejando un gran vacío en la escena nacional e internacional. Una de las creaciones más extraordinarias de este "hombre del Renacimiento" (Peláez Martín, 2015: ed. el.) fue la escenografía que diseñó para Fiesta barroca (1992), un espectáculo de la Compañía Nacional de Teatro Clásico (CNTC), único en su historia, dirigido por Miguel Narros. Andrea D'Odorico ha colaborado con la CNTC en cuatro ocasiones: por un lado, junto a la directora Pilar Miró en El anzuelo de Fenisa (1997) de Lope de Vega; y, por otro, de la mano de Miguel Narros en El caballero de Olmedo (1990) de Lope deVega, Fiesta barroca (1992) de Calderón de la Barca y Quiñones de Benavente y El burlador de Sevilla (2003) de Tirso de Molina. Al margen de esta institución, Miguel Narros y Andrea D'Odorico se han constituido como una de las parejas teatrales más sólidas del panorama teatral actual desde que comenzaran a trabajar juntos en los años setenta, trazando una dilatada y personal trayectoria que acumula más de cincuenta puestas en escena. Como tendremos ocasión de ver, el montaje de la CNTC será un punto de inflexión en la carrera de este tándem profesional².

2 El estreno absoluto se produjo el 2 de julio de 1992 en la Plaza Mayor de Madrid. Fiesta barroca es una coproducción del Comité Organizador de Madrid Capital Cultural 1992 y Telefónica. Para su estudio he recurrido a la grabación realizada el 10/07/1992 que me ha sido cedida por el Centro de Documentación Teatral. La ficha técnico-artística del espectáculo es la siguiente: selección y versión de textos: Rafael Pérez Sierra; documentación: José María Díez Borque; música: Tomás Marco; coreografías: Ana Yepes; iluminación: Josep Solbes; escenografía y supervisión de vestuario: Andrea D'Odorico; dirección escénica y figurines: Miguel Narros; dirección musical: Fernando Poblete; músicos del foso:Víctor Ardelean y Esperanza Velasco (violines), Alan Kovac (viola), Paul Friedhoff (violonchelo), Toni Goig (clarinete), Wade Mattheus (clarinete bajo), Francisco Ramírez (trompeta), Horacio Parravicini (flauta), Rubén Albornoz (oboe), Salvador Arago (fagot), Gils Lebrún (trombón), Sergio Graña, Dionisio Villalba y José Manuel Llorens (percusión); músicos del cortejo: José Luis Tudela (oboe), Miguel Ibáñez (clarinete), Wade Mattheus (clarinete bajo) y José Luis Ferreira (percusión); danza de gigantes y cabezudos: Alicia Suescun (flauta), Juan Muro (clarinete), Vicente Alario Ripoll (fagot) y Sergio Graña (percusión); danza de gitanas: Concepción Vacas (flauta), Ezequiel Lezama (oboe), Ricardo Soto (fagot) y Martín Valdés (percusión); coro: Ángeles Panadero e Isabel Rivero (sopranos), Soraya Chaves y Ana Sandoval (mezzosopranos), Francisco Fernández y Ángel Harkatz (tenores) y Carmelo Cordón y Francisco Sandoval (barítonos). Intervienen en el cortejo: policía a caballo y timbales del Excmo. Ayuntamiento de Madrid, Gigantes y Cabezudos del Excmo. Ayuntamiento de Guadalajara y Grupo de Pecados y Danzantes de Camuñas (Toledo). Coordinación técnica de circo de la Compañía Ale Hop: Fidel Aranda Mayorga, Javier Álvarez Travet, Ignacio Pérez Silva, Vicente Vegas Fajardo, Jorge Brutez Espínola y Antonio Orihuela Velasco (Malabaristas); José María Martínez Silva (Acróbata); Alejandra Oviedo, Mario J. Gallego, Jaime Tamarit y María del Sagrario Cubero (Zancudos); Antonio Cifo Aguilar, Julio Bao Sarmiento y Juan Carlos Simón García Orlando (Gigantes); Luis María Gallego, Francisco Marín, José Luis López, Arsenio Luna, Javier Arnas e l̃ñigo Ibarra (Diablos); Antonio López (Seminarista); Carlos Ucar, José Ma Ureta, Paco Ureña y Pablo Martín (Ediles); Delfos (Figuración).

El reparto estuvo compuesto por los siguientes intérpretes: Loa del auto sacramental El gran mercado del mundo de Calderón de la Barca: Emilio Laguna (El Mundo); María Álvarez (La Modestia); Paz Marquina (La Costumbre); Aitor Merino (La Juventud); Marcial Álvarez (El Albedrío); Juanjo Artero (El Auxilio); Carlos Bernal (El Apetito); Fany Condado (La Lascivia); José Antonio Mayenco (La Hipocresía); Antonio de la Fuente (El Vicio); Esther Lorente 


\section{UN DESAFÍO ESCÉNICO}

En 1992 Madrid fue nombrada Capital Europea de la Cultura, una oportunidad excelente para la CNTC que no dudó en embarcarse en un ambicioso proyecto en el que Narros "aceptó la locura de dirigir a ochenta actores, treinta y cinco bailarines y más de doscientos figurantes" (Andura Varela, 2000: 151)³. Miguel Narros tenía un perfil que sintonizaba plenamente con el espíritu que Adolfo Marsillach había inculcado a la compañía: con una dilatada experiencia en el teatro clásico, su mentalidad moderna y abierta (que mucho debe a Jean Vilar) siempre se había mostrado contraria a la reconstrucción histórica del teatro áureo lo que le llevaría a afirmar que los clásicos hay

(La Envidia); Víctor Manuel Dogar (La Ira); Sonia Almarcha (El Fervor); Pablo Calvo (La Soberbia); Pedro Ga. de las Heras (La Pereza). Folías (Baile de pareja): Begoña del Valle y Diego Llori; Entremés de los Organos de Quiñones de Benavente: Alfonso del Real (El Cura); Ana Goya (Doña María); Jaume Valls (Mochales, Sacristán); Guillermo Montesinos (Serijo, Sacristán) y Herlinda Cembreros (El Ama). Bodas de Serijo (Baile de aldeanos): Ángeles Algar, Javier Escobar, César Casares, Marcos León, Blanca Carabantes y Alma Ma Sarti. Auto sacramental Elgran mercado del mundo de Calderón de la Barca: María José Sánchez (La Fama); José Coronado (El Buen Genio); Vicente Díez (La Malicia); Helio Pedregal (EI Mal Genio); Ana Duato (La Gracia); Carlos Álvarez (El Padre de Familias); Enrique Menéndez (La Inocencia); Rosa Novell (La Culpa, Mozo de Estampas, Caballero Intermediario, Leproso, Esclava); María Álvarez (La Gula, El Apetito, El Placer); Magüi Mira (La Lascivia, La Hermosura Humana); Fernando Conde (EI Mundo); Teresa Vallejo (La Soberbia); Eusebio Gay (El Eclesiástico); Miguel Ramos (EI Militar); Paula Soldevila (La Humildad); Arantxa Aranguren, Ángela Elizalde, Lola Gil y Petra de Tena Rey (Acompañantes de La Humildad); Lía Chadman (Cortejo de la Hermosura Humana); Ramón Serrada (Eldesengaño); Rafael Rojas (La Penitencia); Alberto Díaz, Juan Antonio Somoza y Joaquín Casares (Flagelantes); Fernando de Juan y Balbino Lacosta (La Herejía); Mapi Sagaseta ( $\mathrm{LaFe}$ ); Teresa Arbolí (La Caridad); Martha Castrillón (La Esperanza); Santiago Carrallo, Juan Carlos Alonso, Emilio Cerdá e Ion Garayalde (Servidores de Escena); Sergio Marcus, Amado Cruz, José Luis García y José Antonio González (Porteadores de Lascivia); Gilbert Pachica, Valentín Bosoco, Gaspar Osa y Benjamín Edu (Porteadores de la Belleza). Baile de gitanos: Ma Teresa Chico, Felisa de la Cruz, Roberto de la Cruz, Luz Paloma Flores, Marta Jiménez, Belinda Jiménez, Carmina Navarro, David de la Roda, Isabel Santonja y Miguel Ángel Villalba. Mojiganga de las Visiones de la Muerte de Calderón de la Barca: Anna Briansó (EI Alma); Miguel del Arco (EI Demonio); Nathalie Seseña (El Ángel); Nacho de Diego (EI Cuerpo); Yolanda Kaballero (La Muerte); Paco Torres (EI Carretero); Francisco Vidal (ElAutor); Ángel de Andrés (El Caminante); Carmina Gil (Gitana) y Marcos León (Gitano). Baile de gitanas y gallegos: Ángeles Algar, Josep Ahumada, Blanca Carabantes, Raúl Calderón, Teresa Chico, César Casares, Felisa de la Cruz, Manuel Castillo, Luz Paloma Flores, Roberto de la Cruz, Marta Jiménez, Javier Escobar, Belinda Jiménez, Hugo Gutiérrez, Carmina Navarro, Tomorr Kokona, Isabel Santonja, Marcos León, Alba Ma Sarti, Ton Lovegrin, Miguel Romero, David de la Rosa y Miguel Ángel Villalba.

3 El elevado gasto que supuso el espectáculo Fiesta barroca (en torno a 380 millones de pesetas) provocó numerosas críticas hacia su director Miguel Narros quien se defendió argumentando que no se trata de un derroche: "Todo vale la pena [...]. Nadie se mete con el dinero que se gasta en material bélico y sin embargo el que se gasta en cultura se mira con lupa. Creo que se hacen muy pocas cosas de este tipo, puede pasar una vez cada 50 o 100 años". Además, está convencido de que "estas grandes representaciones se someten a las grandes críticas" (Fernández Rubio, 1992: ed. el.). Seguramente haya sido el montaje más caro de la historia de la CNTC, pero también el más ambicioso y soberbio de cuantos conforman su trayectoria por ser el único capaz de recrear en todo su esplendor el ambiente de la fiesta sacramental barroca. Es, para Andrés Peláez Martín (2000: 121), "el más bello espectáculo que sobre Calderón y el espíritu del barroco se ha llevado a cabo". 
que "hacerlos actuales. Los clásicos tienen que ser nuestros contemporáneos [...]. Hay que tratarlos como se trata una obra contemporánea. Una cierta "falta de respeto" sería una forma de respetar el texto y las situaciones" (Amestoy, 2002: 51)4. Otro aspecto que hacía de Narros la persona idónea para enfrentarse a Fiesta barroca era la idea de teatro como espectáculo total con la que comulga el director, quien es, para Andrés Peláez Martín (2002: 58), "un claro ejemplo de la concepción de totalidad a la hora de crear un montaje puesto que domina tanto la plástica, como la dirección y la interpretación", y que va a encontrar en este montaje su máxima expresión.

El gran despliegue escenográfico y el complejo significado visual y textual de Fiesta barroca van a suponer un punto de inflexión en la carrera del director español si tenemos en cuenta la sobriedad con que aborda cada puesta en escena. Basta recordar las palabras de Miguel Narros (1967: 3) recogidas en el programa de mano de El rey Lear en 1967: "Creo que Shakespeare ha de montarse con una gran sencillez dentro del espectáculo. Un escenario casi vacío y unos pocos elementos son suficientes para atraer la atención del espectador. El texto es lo importante en Shakespeare"; o la observación que hacía Rosana Torres (2013: ed. el.) al recordar, a la muerte del director, su gusto por montajes "de una gran sencillez y austeridad"; en el caso de Yerma (2012), uno de sus últimos estrenos, volvía a inclinarse por una escenificación "sobria y desnuda" que el director justificaba en los siguientes términos: “He elegido esa desnudez porque la verdad no está disfrazada nuncay, siguiendo con mi tradición docente, de jugar con la verdad, como les he enseñado a mis alumnos, tengo que jugar también yo con esa verdad" (Torres, 2012: ed. el.). Y del mismo modo, Javier Huerta Calvo, Emilio Peral Vega y Héctor Urzáiz Tortajada (2005: 500) han incidido en su capacidad para realizar montajes ajenos a cualquier efectismo y extravagancia en los que predomina el equilibrio y el buen gusto. Este planteamiento escénico está estrechamente vinculado al respeto que continuamente muestra por el texto dramático, el verdadero protagonista del hecho teatral. David Ladra (1985:66-67), a raíz de El castigo sin venganza (1985), destacó "su honradez en cuanto a respetar el texto y esa sensibilidad que le es tan propia y que se ha hecho ya característica de sus puestas en escena"; cuando dirigió Macbeth en 1980 la prensa señaló, entre otras cosas, "el riguroso

4 Para Ignacio Amestoy (2002: 28): “Jean Vilar será uno de los grandes maestros de Miguel Narros". En 1951 el director español consiguió una beca que le permitió formarse en París. Allí conoció La Comédie-Française y estudió con Jean Vilar, director del Teatro Nacional Popular de Francia (TNP), con quien aprendió todas las posibilidades de la luz y el espacio a partir de las teorías de Gordon Craig y Adolphe Appia. Vilar enseñó a Narros a ver al actor con otros ojos, a no identificarlo con un personaje sino como creador de miles de personajes. Así recuerda su experiencia junto al director y escenógrafo francés: "El espacio para los montajes de Jean Vilar era muy impresionante. Un escenario monumental que no tenía límites. Y allí era importante la interpretación, los actores. ¡El decorado no existía prácticamente! El decorado era la palabra del autor y el resto era lo que el actor nos estaba dando. En esa compañía estaba Gérard Philipe, Jeanne Moreau y María Casares..." (Amestoy, 2002: 28-30). 
respeto al texto del que se ha partido para montar la representación de la obra" (Carrasco, 1980: ed. el.); y en sus propias declaraciones Miguel Narros asegura que "la obligación de un director de escena [...] radica en lograr que la puesta en escena no ensombrezca nunca al texto" (Torres, 2000: ed. el.). Por estos motivos (y otros que iremos desgranando), Fiesta barroca será un gran reto para el director.

En cuanto a Andrea D'Odorico, la propuesta de la CNTC se presentó como una oportunidad para experimentar con el espacio escénico. Si bien es un escenógrafo con un gran bagaje en teatro clásico, la mayoría de sus trabajos han sido diseñados para el teatro a la italiana. Aun así, siempre ha manifestado interés por otras posibilidades escénicas como confiesa en una conversación con José Luis Alonso de Santos (1984: 39):

Me gustaría muchísimo experimentar con otros espacios, y no me siento un poco aprisionado, sino todo [en cuanto a las limitaciones del teatro a la italiana]. Fíjate, en el Mercader quería hacer cosas en el patio de butacas, pero si lo hago los de la última fila no lo ven. Cuando te planteas un montaje estás muy condicionado por esas tres paredes yeso es terrible, porque puedes hacer muy poco y sería maravilloso poder trabajar en espacios libres...

Así será. En Fiesta barroca la escenografía de Andrea D'Odorico tendrá que interactuar con las calles de Madrid y su Plaza Mayor, un espacio extraordinario en el que sabrá desenvolverse gracias a su faceta de arquitecto ${ }^{5}$, y que le inspirará a la hora de diseñar la escenografía de Mañanas de abril y mayo (2000) ${ }^{6}$. Su perfil de escenógrafo arquitecto es uno de los reclamos de Miguel Narros a la hora de trabajar con un diseñador escénico, como deja patente en el siguiente fragmento:

5 Para Andrea D'Odorico sus dos profesiones (arquitecto y escenógrafo) confluyen de forma plena en el teatro: "son diferentes en lo que se refiere al planteamiento de trabajo, pero desde el momento en que como escenógrafo te planteas un montaje -yo trabajo en planta, no en alzado-comienzan a tener mucho en común. A mí me ha sido muy útil trabajar primero en arquitectura para después dedicarme al teatro". Precisamente su doble perfil abre el debate sobre la naturaleza del escenógrafo (pintor o arquitecto) y qué resulta más conveniente; en este sentido, D'Odorico añade: "yo como arquitecto tengo las ideas muy claras desde el momento en que hablo con el director acerca de un montaje. Sé qué materiales voy a utilizar, cómo lo tengo que resolver... otra cosa son los problemas con los que me encontraré después a la hora de la realización técnica, o de las limitaciones del espacio... El pintor tiene una inspiración más plana y suele olvidar que el teatro se tiene que ver desde la última fila. El pintor se encierra en un dibujo en el que las pequeñas cosas cotidianas tienen mucha importancia, pero no trabaja con las grandes dimensiones que exige el teatro" (Alonso de Santos, 1984: 32). espectáculo, como es costumbre en él, una escenografía simple y muy arquitectónica que rememora los alrededores de la Plaza Mayor y el Madrid de los Austrias" (Torres, 2000: ed. el.). 
Yo empiezo los ensayos con una idea de lo que es el decorado, aunque no sea la definitiva. Utilizamos una plantilla. Muchas veces, Andrea D'Odorico es muycaprichoso, y hay que tragar lo queél hace... Me han dado buen resultado los arquitectos. Andrea D'Odorico, desde luego. Juan Ruesga es arquitecto, y ha trabajado en Sevilla, en una Yerma, que se vio en Madrid en el Lara, con un espacio mutilado. Era jugar con la tierra y con el agua. Fue colaborador mío también otro escenógrafo, Pablo Gago [...]. Yo no estoy nunca de acuerdo con un creativo de la pintura o de la escultura. No tienen una visión del teatro. La visión del teatro es el espacio. Para un pintor, hay un telón plano. Para un escultor, una forma (Amestoy, 2002: 42-43)

Por otro lado, la complicidad que mantiene el escenógrafo con Miguel Narros le permitirá elaborar un discurso teatral sólido y coherente. Así pues, coincide con el director en tomar como punto de partida, para cualquier montaje teatral, el texto dramático (Alonso de Santos, 1984: 38) e, igualmente, es contrario a la reconstrucción arqueológica de las obras clásicas en pro de ofrecer una visión actual de este tipo de teatro, aunque no siempre ha dispuesto de los medios necesarios (tal era el caso de la década de los ochenta):

No obstante volvemos a hablar de las limitaciones que el escenario a la italiana impone. Para poder hacer algo más referido a la actualidad sería preferible contar con espacios polivalentes, y con otros elementos escénicos con los que desgraciadamente no podemos contar (Alonso de Santos, 1984: 41).

Asimismo, la sobriedad y sencillez con que Narros aborda cada puesta en escena armoniza con las escenografías sintéticas y orgánicas de D’Odorico en las que el espacio vacío es uno de sus principales componentes, y que son, para algunos críticos, sus mejores creaciones $^{7}$. La CNTC cuenta con dos buenos ejemplos de esta sobriedad escénica: El burlador de Sevilla (2003), dirigido por Narros, cuya escenografía consistió en un "limpio y austero dispositivo" (Perales, 2014: ed. el.), y El anzuelo de Fenisa (1997) cuya directora Pilar Miró “ha preferido diluir las coordenadas históricas de la trama en su apuesta por un espacio vacío que permita la agilidad de los actores en sus entradas y salidas" (Mascarell, 2014: 287). Pero este tipo de escenografías representan tan solo una de las dos tendencias estilísticas que definen la obra de D’Odorico; la otra se caracteriza por ser todo lo contrario:

7 José Luis Alonso de Santos (1984: 38), en la conversación con D’Odorico, revela abiertamente su postura: "Para muchos, permíteme mi opinión, tus montajes más interesantes como creador escénico son esos espacios vacíos que tú aportas como elementos sintéticos y orgánicos...". Para un recorrido por algunos de los trabajos más célebres de Andrea D’Odorico, véase el artículo "Puestas en escena fin de siglo", de Margarita Almela Boix (2000). 
detallista, barroca y naturalista ${ }^{8}$. Tratándose de un espectáculo como Fiesta barroca, esta última línea, llevada a su máximo esplendor, será la escogida por el escenógrafo.

\section{3. "UNA FIESTA PARA LOS SENTIDOS"}

Entre los colaboradores que hicieron posible Fiesta barroca se contó con la presencia de José María Díez Borque, responsable de la documentación, cuyos primeros pasos son relatados por él mismo en los siguientes términos:

Para elaborar la fiesta sacramental del 92 -no una reconstrucción arqueológica, como se dirá después- era necesario tener conciencia de ese carácter festivo-celebrativo, que, dentro de otros parámetros, se intentó recuperar. Por otra parte, pareció necesario recolectar el mayor número de datos documentales y testimonios gráficos sobre la realización de la fiesta sacramental por los años (1635-1645) a los que parece pertenecer el auto representado [El gran mercado del mundo]. Este criterio de reunir una información amplia y suficiente no iba encaminado, de nuevo, a una imposible reproducción de lo que se hacía en el XVII, sino a una interpretación, a la altura de nuestro siglo, con conocimiento de causa (Díez Borque, 1994: 58).

La fiesta sacramental constituía un acontecimiento único dentro de la"polifónica cultura de la fiesta" que caracterizaba al Siglo de Oro (Díez Borque, 1992: 25). Con una entregada participación del pueblo este espectáculo compartía calendario con otras celebraciones de tipo popular (carnaval, romerías, canciones populares, etc.) y litúrgico (fiesta de la Virgen o de los Santos) que tenían en común la combinación de lo profano y lo religioso. Este evento, de gran complejidad visual, textual y ritual, tomaba la ciudad por completo:

Se produce $-y$ esto es especialmente significativo para la fiesta sacramental- una ocupación espectacular de la calle, articulando arquitecturas fijas y efímeras, adornos, poesías, emblemas, empresas, jeroglíicos..., con un significativo valor de la procesión-Cortejo, en la que

8 Las dos líneas estilísticas que definen la escenografía de Andrea D'Odorico (una sobria y sintética frente a otra preciosista y barroca) son planteadas por José Luis Alonso de Santos (1984:33) de la siguiente manera: "Por un lado el Andrea que hace trabajos escénicos procurando la síntesis, buscando el hueso orgánico del espectáculo como por ejemplo en Lear; y ese otro Andrea más realista, más naturalista y detallista". Algunos ejemplos de este último son El sueño de una noche de verano (1986) y La señorita Julia (2008), dirigidas por Miguel Narros, o La Avería (2011), de Friedrich Dürrenmatt y dirigida por Blanca Portillo; un caso extremo de escenografía "recargada y barroca" (Pérez, 1998: 156) lo encontramos en Petra regalada (1980) de Antonio Gala, dirigida por Manuel Collado. 
hay carros triunfales, diversa utilería (banderas, estandartes, pendones...), ricos vestidos etc., y también con mojigangas festivas, mascaradas, etc. Es la exaltación y celebración que ponen la teatralidad desbordada al servicio de una causa civil y/o religiosa (Díez Borque, 1994: 56).

La celebración comprendía, además de la procesión, varias piezas dramáticas (autos sacramentales, loas, mojigangas y entremeses). En este punto, José María Díez Borque (1994: 62-63) insiste en que el espectador actual debe entender la fiesta sacramental barroca como un complejo mecanismo de recepción del que forman parte distintas piezas, cada una de ellas con una función asignada (el auto es la obra dramática mayor, el entremés y la mojiganga introducen la comicidad y la loa asume la función explicativa, de presentación o de captatio benevolentiae), y que en conjunto "no puede interpretarse de forma simplista según lo que hoy para nosotros es el contraste entre lo cómico y lo serio, transgresión y norma, doctrina y comicidad. Afecta a formas más profundas de articularse lo lúdico, lo doctrinal, el mensaje y la expansión festiva".

A partir del trabajo documental surgieron las principales directrices de Fiesta barroca. El espectáculo se inició con una procesión que partió de la catedral de la Almudena para dirigirse a la Plaza Mayor de Madrid en cuyo recorrido se pudieron contemplar gigantes y cabezudos, gitanas, sacristanes, malabaristas, acróbatas, demonios y seres fantásticos, "acompañados de las espectaculares arquitecturas efímeras de carros y tarascas" consiguiendo "una magnífica procesión, desbordante de colorido y de extraordinaria brillantez plástica, que servía de prólogo al espectáculo que luego se representaría ante la fachada de la Casa de la Panadería" (Andura Varela, 2000: 151)9. A la vista de la descripción que hace Antonio Bonet Correa (1992: 110-111) de la Plaza Mayor de Madrid, no cabe duda de que es el mejor escenario para representar Fiesta barroca:

El regreso, en 1606, de la Corte a Madrid tras cuatro años de estancia en Valladolid, marcó la fecha del crecimiento y mejora de la villa. La obra principal que proporcionó a la capital un centro con categoría arquitectónica fue la Plaza Mayor. De planta rectangular y alzado uniforme, pertenece al tipo de intervención urbana en la cual domina la regularidad. Su traza era de mano del arquitecto Juan Gómez de Mora, cuya obra, de clasicismo postherreriano, configuró estilisticamente el Madrid del primer tercio del siglo XVII. La Plaza

9 Este tipo de procesión, que tiene sus orígenes en las entradas triunfales romanas, se mantuvo en las celebraciones festivas barrocas. Además de representar la exaltación y custodia de la Eucaristía, este cortejo era una ostentación del poder civil y religioso del que participaban las distintas órdenes religiosas, los altos cargos eclesiásticos, el rey, los miembros de diversos Consejos (de Castilla, de Aragón o de la Inquisición, entre otros) y las principales autoridades municipales (Díez Borque, 1992: 31-32). 
Mayor, que con sus casas de cinco pisos supuso una nueva forma de vivir en la ciudad, creó un ámbito apto para las fiestas públicas. Espacio abierto a la vez que cerrado, la Plaza Mayor era como un escenario, un teatro o "corral de comedias" de grandes dimensiones. A diario servía para el mercado de hortalizas, verduras y otras viandas finas. En los días "geniales o lúdicos", para los espectáculos y regocijos colectivos o multitudinarios. Con capacidad para 50.000 espectadores, que se acomodaban en los balcones de las casas y los tablados que se montaban a propósito, la Plaza Mayor fue el foro festivo de la Villa y Corte. En ella tuvieron lugar justas poéticas, canonizaciones, proclamaciones reales, procesiones, rogativas, juegos de cañas y sortijas, cabalgatas, máscaras, ejercicios ecuestres y, sobre todo, corridas de toros. También los Autos de Fe y, como actos excepcionales, las ejecuciones de don Rodrigo Calderón, en 1621, de los dos Padilla y el portugués Cabral, en 1648. La Plaza Mayor, que en el siglo XVII ardió dos veces, en 1631 y 1672, tiene como eje principal la Casa de la Panadería, en cuyo balcón principal se colocaba el rey con su séquito para contemplar espectáculos.

El programa central siguió la fórmula original de loa, entremés, auto sacramental y mojiganga, enriquecido con diversos números de música y danza, un espectáculo que en su conjunto se "ha procurado que fuera una fiesta para los sentidos" (López Mozo, 1992: 8$)^{10}$. La música compuesta por Tomás Marco desempeñaría un papel fundamental (como sucedía en la fiesta sacramental del siglo XVII) en las distintas funciones del texto cantado (oración, explicación, adoración o ambientación sobrenatural)"11. Rafael Pérez Sierra (1992: 1), responsable de la selección y versión de los textos, detalla en el programa de mano por qué escogió cada una de las piezas que componen Fiesta barroca:

Para una ocasión extraordinaria como ésta, el auto, prescindiendo de todos los antecedentes, tenía que ser de Calderón, y de entre todos los suyos elegí cinco: El gran teatro del mundo, El gran mercado del mundo, La cena de Baltasar, Sueños hay que verdad son y No hay más fortuna que Dios, para dárselos a leer al director de escena. Parece inevitable coincidir en la gran teatralidad del primero de los cinco, el más representado, y en la del tercero,

10 Para hacerse una pequeña idea del espectáculo, véase el reportaje de Fiesta barroca disponible en el siguiente enlace: $h t t p s: / / w w w . y o u t u b e . c o m / w a t c h ? v=W K w H v Z j Y d d M[01 / 12 / 2016]$.

11 Para una aproximación a la reiterada colaboración de Tomás Marco con el teatro véase: "Tomás Marco y las artes escénicas en el siglo XXI" (Nieto Yusta, 2016), comunicación con la que participé en el XXIV Seminario Internacional del SELITEN@T Teatro y Música en los inicios del siglo XXI de la UNED, celebrado entre el 24 y 26 de junio de 2015, y dirigido por el profesor José Romera Castillo. Puede consultarse la videograbación en línea: $h$ ttps://canal.uned.es/mmobj/index/id/38562 [25/10/2016]. 
aun siendo menos perfecto. Sueños hay que verdad son ofrecía alguno de los recursos dramáticos que Calderón maneja con más habilidad, pero obliga a reproducir la gastada estampa de José en Egipto. No hay más fortuna que Dios presenta el mismo tema de El gran teatro del mundo con distinta alegoría y es, para Alexander A. Parker, uno de los más perfectos, aunque en escena la alegoría que se desprende del árbol puede resultar pobre. Por todo ello, creo que la elección de El gran mercado del mundo es quizás la más oportuna. En cuanto a las piezas breves, la loa es la del propio auto, si bien algo reformada; el entremés [Entremés de los órganos], del mayor especialista en el género, presenta unas figuras que pueden transitar con toda naturalidad en el cortejo y su brevísima peripecia acentúa la importancia que tiene la música en la fiesta sacramental, aunque por encima de todo tengamos que colocar el desenfado y la riqueza verbales, virtudes fundamentales del entremés en general y en mayor grado de los entremeses de Quiñones de Benavente. Por último, de la mojiganga [Las visiones de la muerte, de Calderón] sólo tengo que decir que fue elegida por unanimidad ${ }^{12}$.

La loa que abre la representación propiamente dicha es un texto sencillo que resume los principales elementos del auto sacramental e invita al espectador a acudir al mercado y a sumarse a la celebración ${ }^{13}$. El Entremés de los órganos de Quiñones de Benavente, uno de los mayores especialistas de este género, narra la disputa de dos sacristanes por la sobrina de un cura que se decantará por el que demuestre mayor talento tocando el órgano, dando pie a situaciones cómicas que culminan con un baile final. La Mojiganga de las visiones de la muerte, con que se clausura Fiesta barroca, relata las alucinaciones que sufre un caminante al adentrarse en el bosque ocasionadas, en realidad, por unos actores que acaban de actuar en un pueblo cercano y que aún portan el vestuario de demonio, ángel, alma y cuerpo. El habitual recurso del teatro dentro del teatro da pie a todo tipo de confusiones, persecuciones y escenas cómicas, y por sus características "es, sin duda, la pieza más 'calderoniana' del conjunto de las obras cortas del autor" (Rodríguez y Tordera,

12 En otra entrevista, Rafael Pérez Sierra recuerda las circunstancias en las que se gestó Fiesta barroca: “Adolfo [Marsillach] quería hacer una naumaquia en el Retiro, pero no nos lo permitían. Como no era creyente, nunca hubiera pensado en hacer un auto sacramental. Pero el director del comité organizador del evento era un dominico y estuvo muy de acuerdo con el proyecto de la Fiesta barroca que le propuse [...]. Teníamos mucho dinero y eso nos permitió traer a Madrid bueyes del Rocío o la Tarasca del Corpus de Valencia. ¡Todo un despliegue!" (Mascarell, 2014: 432).

13 La loa escogida acompaña a El gran mercado del mundo en la edición de Pedro de Pando, pero hay críticos que la localizan junto a Los misterios de la misa en el manuscrito 14.769 de la Biblioteca Nacional de Madrid (Díez Borque, 1992: 43). 
1983: 369) ${ }^{14}$. A diferencia del auto calderoniano, estas tres piezas carecen de apoyo escenográfico: se desarrollan sobre el escenario vacío levantado en la Plaza Mayor y es el vestuario el que goza de total protagonismo junto a algún elemento de utilería (el órgano en el que tocan los sacristanes o la tela blanca que sirve de fondo a los actores de la mojiganga durante su representación). Por este motivo, centraremos toda nuestra atención en la pieza principal.

El gran mercado del mundo es un auto sacramental compuesto en la primera época de Calderón, aproximadamente entre 1636 y $1638^{15}$. Recordemos que el auto es una pieza en un acto que gira en torno al tema de la Eucaristía con unas figuras alegóricas que representan la lucha entre el Bien (catolicismo) y el Mal (enemigos de la fe) para ofrecer una lección moral al espectador. Destinado a representarse el día del Corpus Christi, esta fiesta ha ido incrementando sus elementos espectaculares desde el siglo XIV consagrándose a principios del siglo XVI con Gil Vicente, Sánchez de Badajoz y López de Yanguas; Lope de Vega elevó el auto sacramental a cotas más altas alcanzando su máximo desarrollo con Calderón, autor de más de ochenta autos cuyos máximos exponentes son El gran teatro del mundo, El gran mercado del mundo y La cena del rey Baltasar. A diferencia del resto de autores, Calderón consiguió reforzar los argumentos, potenciar el conflicto entre personajes e intensificar el dramatismo de los temas y su teatralidad (Huerta Calvo, Peral Vega y Urzáiz Tortajada, 2005: 50). En el estudio que hace Ana Suárez (2003) sobre El gran mercado del mundo encontramos las claves para aproximarnos a esta obra. Calderón recurre a los códigos, hábitos y vocabulario propios del mundo mercantil (y de la compraventa) para poner de relieve las consecuencias que cada uno de estos actos tiene sobre el individuo que los lleva a cabo $^{16}$. Se trata de afrontar desde un prisma alegórico la relación que mantiene el espíritu cristiano con el materialismo, esto es, los conflictos que surgen entre la vida espiritual y la vida terrenal siendo el mercado la mejor metáfora para exponer esta dualidad. Calderón no duda en recurrir al característico juego de espejos

14 Rodríguez y Tordera (1983: 369-370) fechan la composición de la Mojiganga de las visiones de la muerte en torno a 1655 y su representación entre 1673 y 1675.

15 Esta es la datación aproximada que ofrece Ana Suárez (2003: 17), "aunque no hay documentos que permitan asegurar la fecha de composición". José María Díez Borque (1992: 35) también incide en que "por desgracia ninguna certeza hay al respecto", pero propone localizar su composición y celebración entre 1635 (fecha emblemática por la muerte de Lope de Vega) y 1645 (año en que consta la primera representación de autos sacramentales en los corrales de comedias madrileños).

16 El contexto mercantil en el que se enmarca El gran mercado del mundo no es un motivo baladí, como advierte Ana Suárez (2003: 18-20): “Lo interesante de Calderón es que bajo su discurso religioso se encierra toda una teoría jurídica y social que coincide plenamente con los planteamientos económicos más avanzados de su época y que manifiestan una vez más la preocupación del dramaturgo por la realidad [...]. Es difícil encontrar otro ejemplo literario en donde se puedan hallar tantas denominaciones del mundo mercantil, desde la acumulación de bienes (mayorazgo) a la relación e intercambio de mercancías (mercado, feria, plaza) y las consecuencias sociales de la práctica económica (mendigos, holgazanes, limosna, pobreza, mal vestidos)". 
barroco para ofrecer imágenes simétricas o contrapuestas del tipo apariencia/realidad, bien/mal, comprador/vendedor, ganancia/pérdida o dinero/mercancía, o que afectan a la propia estructura del auto (dos hijos, dos caminos y dos destinos). Por otro lado el título nos remite al célebre auto sacramental de Calderón El gran teatro del mundo con el que comparte numerosos rasgos:

En los dos autos se muestra la aparición del hombre sobre la tierra (aunque de forma diferente) y se advierte que la vida (en comedia o compra) no puede ser ensayada porque una vez que se tiene su recorrido es único y definitivo. Acertar o no acertar, equivalente a emplear bien el talento (para actuar o comprar), depende de la libertad de cada cual, puesto que todos los hombres reciben las prendas necesarias para lograr el triunfo. La actualización del viejo tópico del mundo como teatro se corresponde con el también antiquísimo del mundo como mercado (Suárez, 2003: 29).

A diferencia de nuestro auto sacramental, El gran teatro del mundo posee una estructura más ordenada, un lenguaje preciso y una bella versificación que explica su constante difusión sobre las tablas, llegando a alcanzar una notable fama entre el público actual. Sin embargo, a la hora de idear el montaje de la CNTC, se prefirió El gran mercado del mundo porque, a pesar de ser menos conocido por el público y más imperfecto en su construcción, tiene "algunos apuntes realistas que moderan, hasta donde es posible, su carácter simbólico y la carga teológica propia de estos sermones versificados" (López Mozo, 1992: 18). Su argumento nos presenta al Padre convocando a sus hijos (el Mal Genio y el Buen Genio) para hacerles saber que solo uno de ellos será el heredero. Para ello deben acudir al mercado del Mundo e invertir su talento en aquello que consideren adecuado. Cuando regresen se juzgarán sus acciones y el que haya obtenido más bienes recibirá a Gracia (mujer de la que están enamorados), la herencia de su padre y su propio reino. Durante su travesía son tentados por la lascivia, la gula, la culpa o la soberbia, pero también se les aparecen la humildad, la penitencia y la fe. El Buen Genio comprará llantos, pesares y una hostia sagrada, mientras el Mal Genio se limitará a adquirir ricas telas, flores, dulces e incluso un esclavo. El conflicto se resuelve, finalmente, a favor del Buen Genio y culmina con la idea de la libertad para elegir entre el bien y el mal y sus consecuencias ${ }^{17}$.

Los dos espacios dramáticos en los que transcurren estas escenas son los que enmarcan el mito del peregrino o caminante (ligado a su vez al tema del hijo pródigo): un entorno natural simbólico (valle y montaña) que abre y cierra el auto, y un núcleo

17 Esta estructura no hace sino reproducir el esquema platónico en el que los hombres, tras ser creados y depositados en la tierra, debían volver al Hades para ser juzgados por sus actos, pudiendo gozar de la vida eterna o, por el contrario, ser enviados al infierno. 
urbano (ciudad con mercados y mesones para acoger a los viajeros) ${ }^{18}$. Andrea D'Odorico ignorará estos espacios dramáticos y reducirá la escenografía al modelo característico de los autos sacramentales: un tablado vacío (en este caso levantado en la Plaza Mayor) y varios carros o carrozas a su alrededor cuyo diseño está inspirado en las ilustraciones de Juan Gómez de Mora ${ }^{19}$ y en los dibujos del Archivo de la Villa, entre otros documentos (Peláez Martín, 2000: 120). Se trata de tres carrozas que representan los tres ejes vertebradores del auto de Calderón: el Mundo, el Bien y el Mal20. Los carros o carrozas eran un elemento imprescindible en este tipo de celebraciones festivas. Estas "máquinas rodantes", conocidas en Valencia como "rocas", tenían forma de nave y portaban estandartes, mástiles con banderas y todo tipo de arquitecturas, ornatos y figuras que simbolizaban alegorías. Podían ser de carácter profano o religioso, lo que derivaba en dos tipos de carros, "serios" o "jocosos": "herederos del carroccio renacentista, los Carros serios tenían un carácter triunfal y grave que completaba el desfile que les precedía. Los Carros jocosos, con figuras ridículas, "a lo faceto", tenían un carácter satírico" (Bonet Correa, 1986: 46). Dado el carácter religioso del auto sacramental y de la festividad del Corpus Christi que acogía este tipo de representaciones, los carros diseñados por Andrea D’Odorico serán "serios", como veremos a continuación.

En la primera carroza (Fig.1 y Fig.2), colocada en el lateral izquierdo del escenario, Andrea D'Odorico ha seguido con fidelidad los modelos escenográficos del siglo XVII. Porta una inmensa esfera o globo del mundo en cuya superficie se ven las divisiones cartográficas que delimitan los continentes, los mares, los meridianos, etc. (Fig.3). En un momento de la representación un mecanismo abre la esfera "en gajos" (Fig.4) y de su interior sale el personaje del Mundo que se dispone a acudir al mercado para conocer a

18 Simbólicamente el valle, lugar propicio para la vida, está relacionado con la imperfección frente al cual se contrapone la montaña, símbolo de la ascensión espiritual y por ende, lugar perfecto y definitivo para el hombre. El espacio urbano, con sus mesones y mercados, es lugar de perversión y engaño donde los hombres se ven desposeídos de su dignidad; de ahí la presencia de mendigos, holgazanes y siervos. Como advierte Ana Suárez (2003: 58): "el autor ha dibujado un perfecto topos cósmico en el que la Naturaleza (valle y montaña) simboliza la eternidad frente a la historia que se despliega por el espacio urbano representativo de la temporalidad (mesones, mercados y corte con el espectáculo pasajero)".

19 El arquitecto Juan Gómez de Mora (1568-1648) trabajará al servicio de Felipe III, cuando este lo nombre, en 1611, "Maestro Mayor de las obras reales”, cargo que le permitió realizar diseños y proyectos arquitectónicos que continuará con el monarca Felipe IV. Entre sus principales aportaciones a la capital se encuentra el Alcázar, la Plaza Mayor y el Ayuntamiento. También diseñó numerosas arquitecturas que formaron parte de festejos y celebraciones durante el Barroco, entre ellas, la fiesta sacramental, siendo especialmente conocidos sus diseños de los carros de los autos sacramentales.

20 En la procesión inicial, además de estas tres carrozas, circuló una tarasca, "un dragón de color rojo recuperado por artistas falleros de hoy a partir de pinturas barrocas, que representa la parte lúdica de las procesiones del Corpus y de la Primavera" (Ruiz, 1992: ed. el.). Durante la escenificación del auto sacramental la tarasca estará ausente y serán las tres carrozas las que ocupen el fondo y los laterales del tablado. 
sus integrantes, los vicios y las virtudes (vv. 830-851) ${ }^{21}$. El globo del mundo era un recurso escenográfico habitual (casi imprescindible) en los autos sacramentales de Calderón como prueban sus "memorias de apariencias", documentos en los que se detalla su decoración y el modo en que debían abrirse estas esferas para provocar un gran efecto sobre el público, indicaciones que D'Odorico parece haber seguido al detalle. Uno de los ejemplos más explícitos corresponde a las "memorias de apariencias" del auto La vida es sueño (1673) que es, a su vez, un magnífico testimonio del esplendor de la escenografía barroca:

El primer carro ha de ser un globo, lo más capaz que pueda dar de sí la fachada del carro; su primer cuerpo ha de estar pintado de boscajes y entre ellos varios animales, y el globo lineado como mapa de esfera terrestre y entre sus líneas cuajado de rosas y flores, lo más hermoso que se pueda. Ha de haber delante dos árboles de recortado en que descanse a su tiempo el medio globo, que se ha de abrir en dos mitades, y de la que queda fija ha de salir una mujer caballera en un león corpóreo.

El segundo carro ha de ser otro globo, igual en sus tamaños al primero, con diferencia de que su pintura ha de ser en su primer cuerpo de nubarrones y estrellas, y en su globo lineado como esfera celeste con signos y imágenes del zodíaco, y todo con resplandores. También se ha de abrir a su tiempo, descansando la mitad que cae en dos colunas de recortado pintadas como pirámides de fuego, y ha de salir de la otra mitad que queda fija otra mujer caballera en una salamandra también corpórea.

El tercer carro ha de ser otro globo igual a los dos, con diferencia de que su pintura sea de color de mar, cuajado entre ondas cerúleas todo de diversos pescados. Su mitad ha de descansar sobre otros dos pies pintados de ovas, conchas y corales, y demás adornos marinos, y salir dél otra mujer caballera en un delfín corpóreo.

El cuarto carro en correspondencia de los tres ha de ser pintado de color de aire, cuajado de diversas aves. Ha de descansar su medio globo en dos bichas con dos pájaros en su remate. La mujer que ha de salir de él ha de venir sobre una águila corpórea (Escudero y Zafra, 2003: 139-140).

21 Los versos de El gran mercado del mundo a los que hago referencia pertenecen a la edición de Ana Suárez (Calderón de la Barca, 2003). 


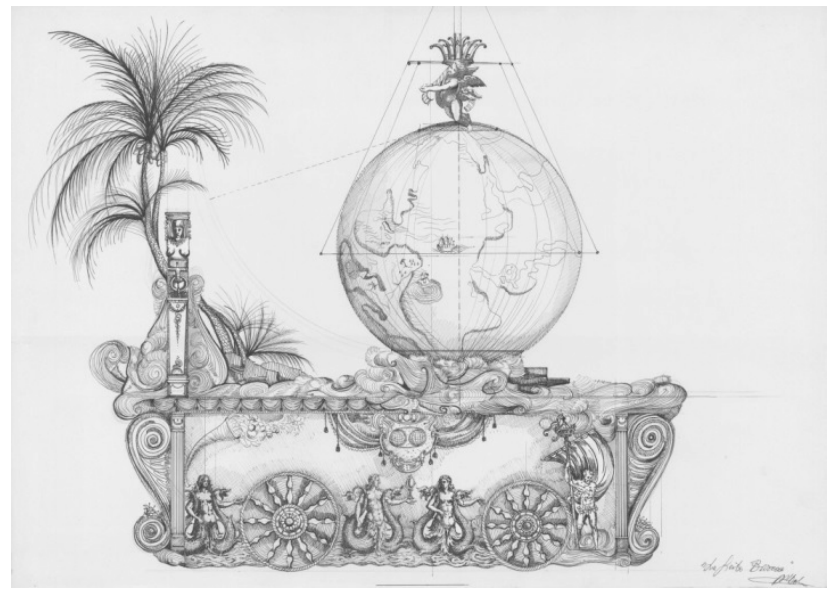

Figura 1. Boceto de la carroza del Mundo

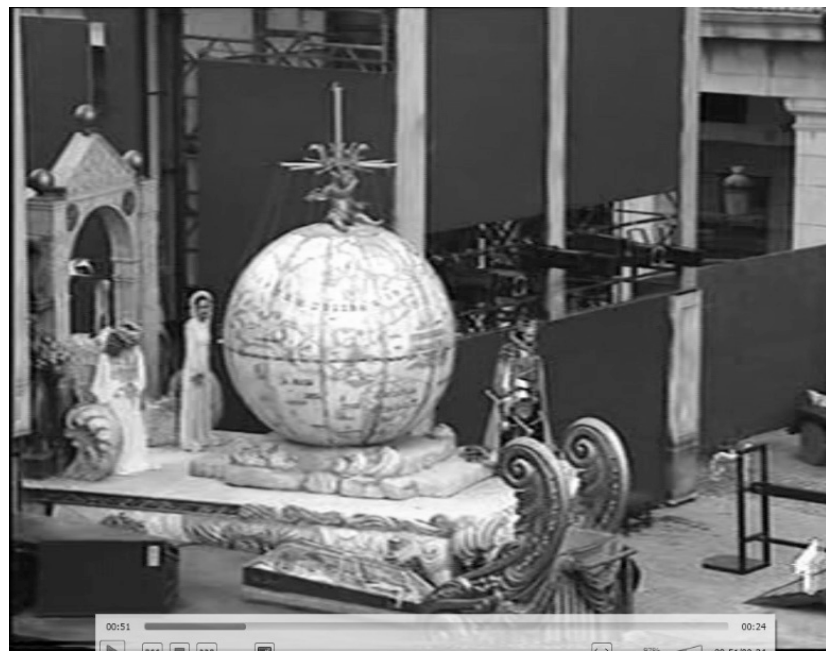

Figura 2. Carroza con la esfera del Mundo

Fuente: Centro de Documentación Teatral/INAEM. Grabación audiovisual realizada el 10/07/1992.

Podríamos añadir las "memorias de apariencias" de El sacro Parnaso (1659), la segunda versión de El divino Orfeo (1663), Lainmunidad del sagrado (1664) o La divina Filotea (1681) ${ }^{22}$ en las que el globo del mundo sigue siendo protagonista indiscutible de la escenografía. Aurora Egido (1995: 3-36) dedica un completo estudio a la presencia del mundo en los autos de Calderón y observa que el autor barroco distinguía entre la geografía y la cosmografía (al igual que Pedro Apiano y Pérez de Moya) dados sus conocimientos sobre

22 Las fechas que aparecen junto a estos autos sacramentales corresponden a las "memorias de apariencias". 
las distintas partes del mundo y sus climas, así como los círculos celestes y sus elementos. Los globos del mundo que ideaba como escenografía para sus autos sacramentales recogían los estudios que habían elaborado diversos cosmógrafos sobre cartas planas, estableciendo una relación ciencia-teatro o geografía-arte que no era tan inusual en la época como pudiera pensarse, y que encuentra uno de sus mejores ejemplos en la obra Magnum Theatrum Vitae Humanae (1678) del geógrafo alemán Laurentio Beyerlink la cual formaba parte de la biblioteca de Calderón y que bien pudo inspirarle para elaborar el complejo programa de sus autos (si bien, el uso de escenografía terrestre y celeste no es una novedad del Barroco; ya formaba parte del teatro medieval y renacentista). El acto de trasladar estas nociones cosmográficas al teatro y plasmarlas en estas esferas que interactúan con las distintas alegorías (el Mundo, la Naturaleza, los Elementos...) es para Aurora Egido (1995: 14) un gesto de gran originalidad porque "los globos y sus personificaciones reducían a pequeña escala los espacios del cosmos y sus funciones, ofreciendo en brevísimo tiempo la historia completa de la humanidad", lo que revela la ambición de Calderón por "remedar en cada auto la gran obra de arte del universo"23. El uso teatral de este tipo de esferas podría tener su precedente en las fiestas acuáticas, de tipo religioso y civil, que se celebraban en la Venecia del Renacimiento donde se utilizaba un tipo de construcción denominada treatri del mondo "de la que Calderón y otros dramaturgos pudieron tener noticia por los escenógrafos de la corte que hicieron realidad sus memorias de apariencias o por las muchas relaciones publicadas sobre tales festejos" (Egido, 1995: 15) ${ }^{24}$.

23 La imagen del mundo como esfera o globo ha desembocado en una compleja iconografía de la que se han servido muchos pintores (El Bosco o Pieter Brueghel entre otros) para ofrecer interpretaciones morales o asociadas a proverbios y refranes que advierten al hombre de las tentaciones y vicios del mundo, y que hoy sigue siendo motivo de reflexión para muchos artistas como Darío Villalba. Para una breve aproximación a la iconografía de la esfera en la Historia del Arte véase mi artículo "Las carceri de Darío Villalba: los encapsulados" (Nieto Yusta, 2010).

24 Se trataba de construcciones realizadas en madera y estuco, de planta redonda o ideadas para sostener edificios esféricos. Estaban dispuestas sobre una tabla sobre la que se apoyaban dos embarcaciones en las que se celebraban bailes y otros eventos teatrales. Los treatri del mondo han sido estudiados en profundidad por Lina Padoan Urban. 


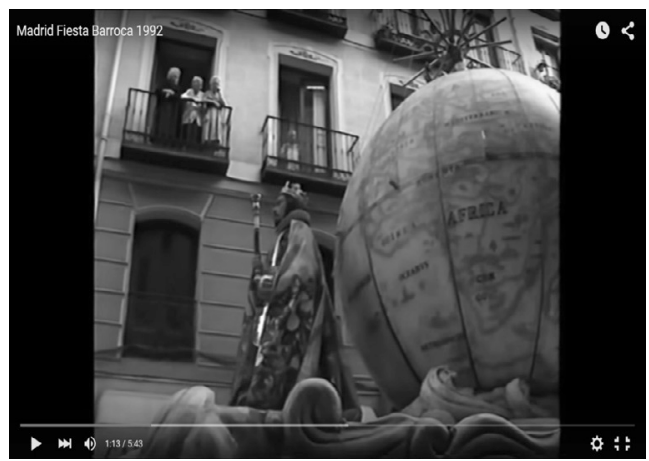

Figura 3. Esfera del Mundo con las divisiones cartográficas.

Fuente: Centro de Documentación Teatral/INAEM. Grabación audiovisual realizada el 10/07/1992

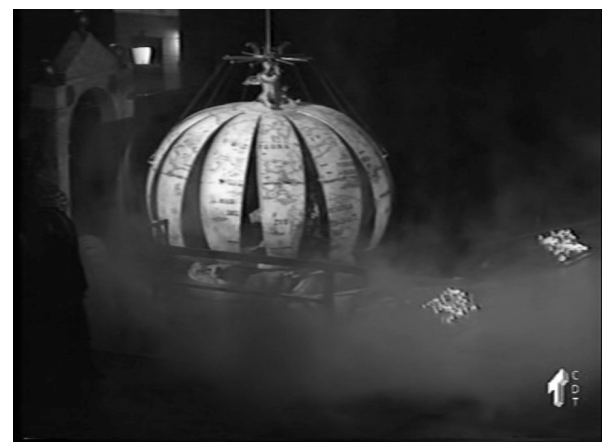

Figura 4. Instante en el que se abre la esfera del Mundo.

Fuente: Centro de Documentación Teatral/INAEM. Grabación audiovisual realizada el 10/07/1992

La segunda carroza (Fig.5 y Fig.6) representa el Bien o el Paraíso y porta un templete de columnas salomónicas cuya cúpula está decorada, en su interior, con motivos celestes. Como hemos visto, uno de los espacios dramáticos en los que transcurre El gran mercado del mundo es el valle o la montaña, un espacio que abre y cierra el auto y que simboliza el Paraíso, como señala Ana Suárez (2003: 52): "el valle inicial (Paraíso) se corresponde con el valle final en donde se alza el cielo al que el Padre lleva al hijo"; el monte es, también, para Antonio Cortijo (2006: 92) "símbolo del anhelo de inmortalidad y de unión del hombre con Dios". Calderón recurre a la imagen del valle y la montaña porque su verticalidad está directamente relacionada con el ascenso del hombre al cielo, una lectura que se corresponde con la carroza de Andrea D'Odorico cuyo estrecho templete, de formato claramente vertical, culmina en una cúpula decorada con motivos celestes. En esta edificación reposa el personaje del Padre (Dios) durante toda la representación, y será él quien juzgue al Buen Genio y al Mal Genio para valorar las acciones cometidas en el mercado del mundo, salvando al 
primero y condenando al segundo (esto es, el Juicio Final). Por otro lado, el uso que hace D'Odorico de columnas salomónicas no recae en ningún anacronismo porque el modelo de columna salomónica fue consagrado en el primer tercio del siglo XVII por Bernini, cuando este esculpió su célebre baldaquino para la basílica de San Pedro de Roma; si bien, en España ya se conocía este tipo de columnas gracias al tratado Regola delli cinque ordini d'architettura (1562) de Giacomo da Vignola. Pero no nos interesa centrarnos en estas columnas como elemento arquitectónico sino detenernos en su simbolismo que nos remite al templo de Salomón. Esta imagen está presente en varios autos sacramentales de Calderón, entre ellos El sacro Parnaso donde encontramos el templo de Salomón representado por el Templo de la Fe, como explica Antonio Cortijo (2006: 92-93):

Un tercer signo semiótico está constituido por el edificio arquitectónico del Tribunal o Templo de la Fe. Este signo se subsume en el anterior, pues en un nivel el Templo de la Fe es trasunto del Templo de Salomón, aunque ahora con el significado de Nuevo Templo. Este Nuevo Templo es también proyección presente a través de la Ley de Gracia del Pacto Antiguo de Dios; y es también signo que se proyecta hacia el futuro a través de la ecuación Tribunal de FeTribunal del Juicio Final. Así, la imagen sólida del templo se une a las imágenes de la totalidad abarcadora y del ascenso del anhelo.

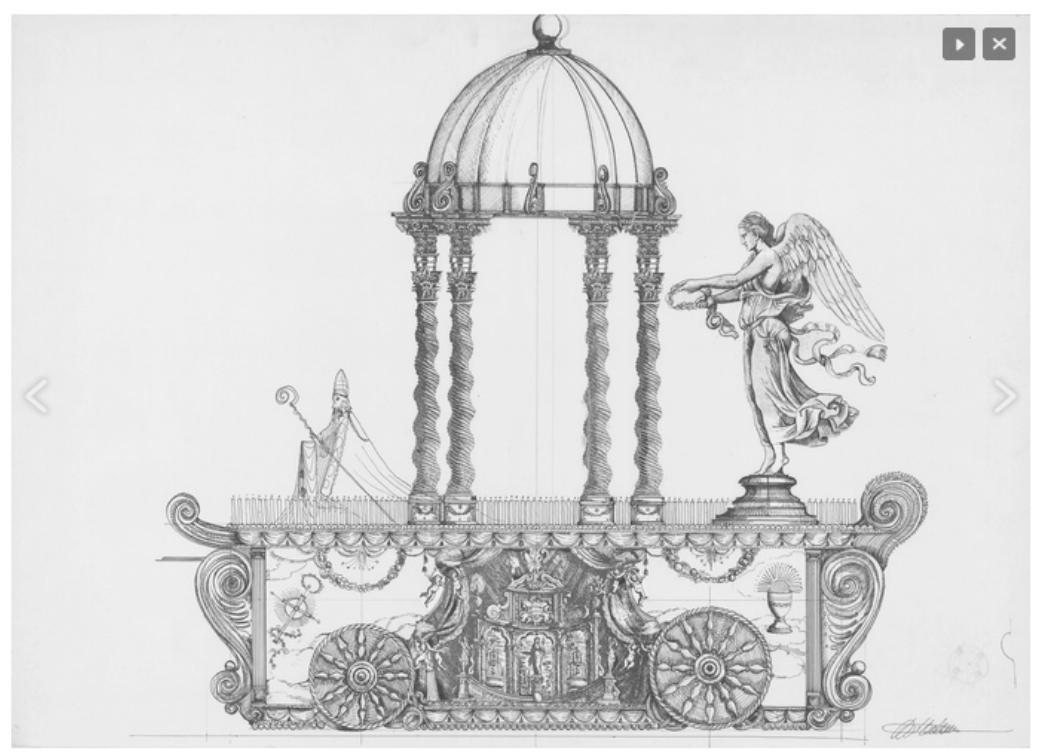

Figura 5. Boceto de la carroza del Bien o del Paraíso

Fuente: http://museoteatro.mcu.es/andrea-dodorico-fiesta-barroca-1992/[25/10/2016] 


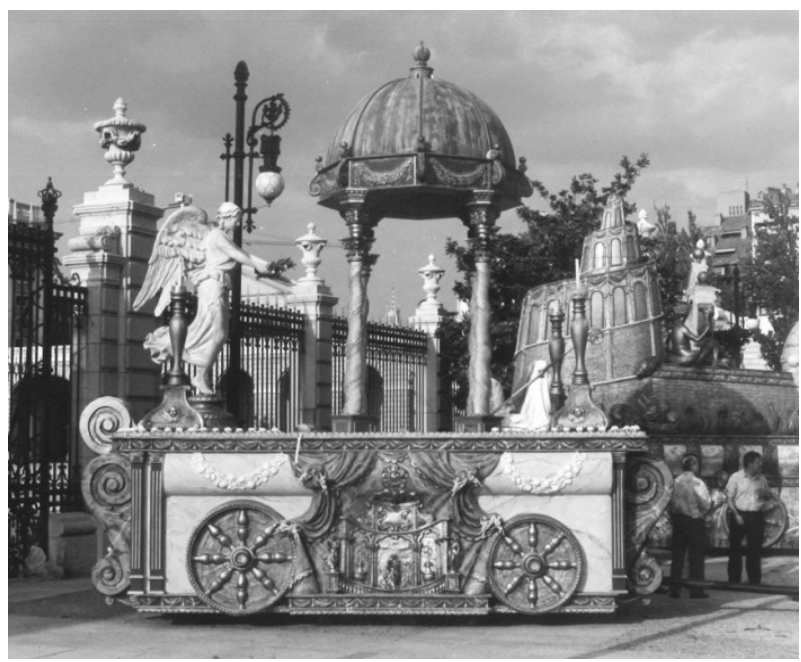

Figura 6. Carroza del Bien o del Paraíso

Fuente: http://museoteatro.mcu.es/andrea-dodorico-fiesta-barroca-1992/[25/10/2016]

No sabemos con certeza si esta era la intención de Andrea D'Odorico a la hora de diseñar esta carroza, pero son notables las similitudes entre la identificación del templo de Salomón con la Fe y con el Juicio Final al que se refiere Cortijo y el significado que cobra el templete en el montaje de Fiesta barroca.

La tercera carroza que completa el tríptico ${ }^{25}$, situada en el lado derecho del escenario, representa el Mal o el Infierno (Fig.7) y porta lo que parece ser una gran torre de $\mathrm{Babel}^{26}$. Al igual que la esfera, el uso de la torre como elemento escenográfico también era habitual en los autos sacramentales de Calderón como nos recuerdan las "memorias de apariencias" de Llamados y escogidos (1643), El primer refugio (1661), Mística y real Babilonia (1662), primera parte de El santo rey don Fernando (1671), ¿Quién hallará mujer fuerte? (1672) y La viña del Señor (1674). Ahora bien, la decisión de introducir la torre de Babel en el montaje de la CNTC ha sido una elección personal de Andrea D'Odorico: si repasamos El gran mercado del mundo, no encontramos ninguna acotación que indique que el Infierno deba estar representado por esta imagen, pero sí hallamos una referencia a Nembrot en los versos 716 a 721. Según Constance H. Rose (1983: 610), Babilonia es para Calderón un lugar bíblico-histórico que le ha servido de inspiración para algunos de sus autos como el ya mencionado Mística y real Babilonia, La cena de Baltasar y La Torre

25 El esquema tripartito (Paraíso-Mundo-Infierno) que conforman las carrozas tiene su correspondencia con el exterior de la Plaza Mayor que fue decorado con fragmentos del Paraíso, el Infierno y el Purgatorio de la Capilla Sixtina de Miguel Ángel.

26 Así lo identifica Jerónimo López Mozo (1992: 18): “Sobre las carretas, el globo terráqueo que representa El Mundo, la torre de Babel símbolo del Infierno y el templete que cobija al Bien". 
de Babilonia; pero es también "tierra de idolatría, de confusión, de soberbia" en recuerdo de la ambición que llevó a Nembrot a construir una torre tan alta que pudiera competir con el cielo. Un simbolismo similar le atribuye Valentina Nider (2007: 30):

Al mencionar la "torre de Babilonia", los escritores del Siglo de Oro aluden generalmente al símbolo de soberbia y presunción, tanto como término de parangón para ensalzar la magnificencia de un edificio, como en su acepción metafórica para referirse a la ambición amorosa o política.

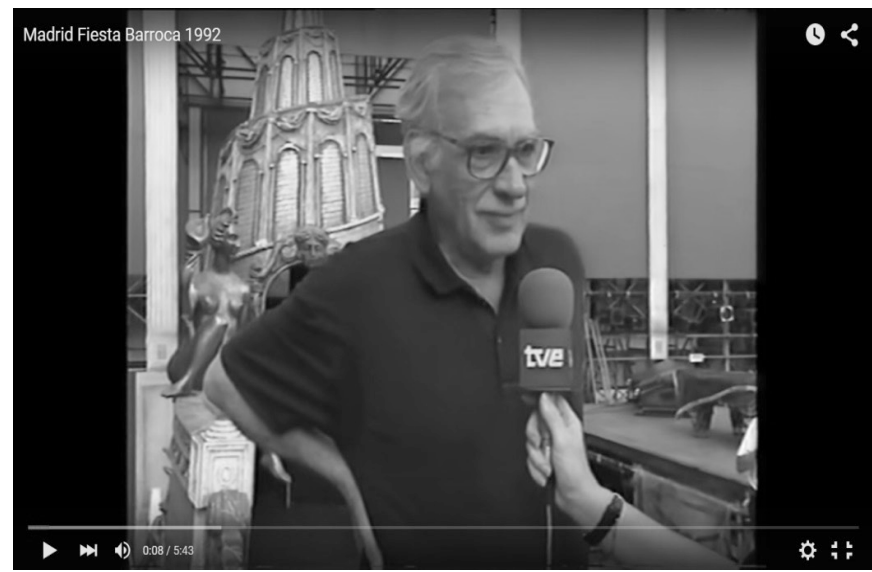

Figura 7. Miguel Narros durante una entrevista, con la torre de Babel al fondo. Fuente: $h t t p s: / / w w w . y o u t u b e . c o m / w a t c h ? v=W K w H v Z j Y d d M[25 / 10 / 2016]$

El paralelismo existente entre Nembrot y el Mal Genio (personaje de El gran mercado del mundo cuya soberbia le condujo al Infierno), podría haber llevado a D'Odorico a escoger la imagen de la torre de Babel como símbolo de esa soberbia. Valentina Nider (2007), en su estudio sobre el auto La torre de Babilonia, dedica un capítulo a la circulación del tema de la torre de Babel en el Siglo de Oro y hace un recorrido por la iconografía de esta construcción consolidada, principalmente, a partir de la interpretación de Pieter Brueghel. En líneas generales hay dos tipos de torre: helicoidal (el modelo escogido por Andrea D'Odorico) y piramidal. Los pintores flamencos adoptaron la torre helicoidal de siete pisos "quizás a raíz de las descripciones de los zigurat en la obra de Heródoto" que frecuentemente toma "un aspecto parecido al coliseo para censurar implícitamente la nueva Babilonia romana" (Nider, 2007: 27). A comienzos del Barroco los pintores todavía se mostraban influidos por el modelo de Brueghel por lo que siguen reproduciendo la imagen de una torre inacabada en la que participan miles de operarios y donde interesa 
detallar las técnicas de construcción. Más adelante hubo nuevas interpretaciones, entre ellas el grabado del jesuita alemán Athanasius Kircher recogido en Turris Babel (1679) consistente en una larga hélice que se eleva hasta el cielo. En un paso más, Valentina Nider (2007: 28) recurre a las acotaciones del auto La torre de Babilonia para aproximarse a la idea que tenía el propio Calderón de esta construcción: “Calderón debía de concebir la torre con muchas aberturas, quizás pensando en la pauta ya utilizada en otros edificios similares que aparecen en los autos [...] para que los personajes pudieran entrar y salir" a lo que debemos añadir el hecho de que "en muchos testimonios se indica que la torre es una obra que va subiendo delante de los ojos del público". Cuando se escenificó La torre de Babilonia en 1637 en Yepes se precisaron, mediante un contrato, las medidas de esta construcción, y según observa Charles Davis (2007: 201) debió de ser una torre imponente por su tamaño; y "si se acepta la hipótesis de una construcción escalonada, las dimensiones horizontales, que parecen relativamente grandes, corresponderían al tamaño de la base; la cumbre sería algo más estrecha". Lo que a mi juicio interesa destacar aquí no es tanto saber qué modelo concreto ha podido inspirar la tercera carroza de Fiesta barroca como poner de relieve la rigurosa y completa documentación que ha llevado a cabo Andrea D'Odorico (y todo el equipo de Miguel Narros) a la hora de diseñar esta escenografía ${ }^{27}$, puesto que son muchas las coincidencias que presenta esta torre con los modelos iconográficos y escenográficos de la época: se trata de una torre helicoidal (modelo aceptado en el Barroco); dispone, en la parte inferior, de una apertura practicable para permitir la entrada y salida de los actores (acorde al tipo de construcciones que se empleaban en la celebración de los autos); $y$, siguiendo el trazado helicoidal, Andrea D'Odorico ha dispuesto una escalera que permite a los actores subir y bajar por la torre, más ancha en su base y más estrecha en la parte superior (una de las posibilidades contempladas en la escenografía del auto La torre de Babilonia, representado en Yepes). Se trata de una interpretación libre, una mezcla de referencias históricas y fantásticas pero en todo momento "con conocimiento de causa", retomando las palabras de José María Díez Borque (1994: 58). Así lo ha percibido la crítica al referirse a Fiesta barroca como "un espectáculo brillantemente infiel al modelo" (López Sancho, 1992: 105).

Detengámonos en un aspecto más antes de finalizar. Además de la procesión inicial y las cuatro piezas dramáticas (loa, entremés, auto y mojiganga), Miguel Narros

27 Este modus operandi es característico del director y el escenógrafo. En el caso de Andrea D’Odorico, muy influido por su maestro el arquitecto Carlo Scarpa, "era siempre muy riguroso, estudiaba todas las fuentes documentales y gráficas para alcanzar las claves del texto teatral. Cuidaba los detalles de manera obsesiva, tanto los colores, como el diseño de un mueble por mínimo que fuese", como recuerda Andrés Peláez Martín (2015: ed. el.), quien asegura que "la perfección y la elegancia fueron columnas inamovibles en toda su obra creativa". 
enriqueció el espectáculo con distintos tipos de bailes populares que alternó durante la representación: unas folías (baile de pareja), unas bodas de Serijo (baile de aldeanos), un baile de gigantes y matachines, un baile de gitanos, y para clausurar el espectáculo, un baile de gitanas y gallegos. No es casualidad que el director haya incluido este tipo de danzas en el programa de Fiesta barroca dada su gran cultura teatral: estos bailes formaban parte de uno de los eventos populares por excelencia, el carnaval, cuya presencia durante el Siglo de Oro "está todavía muy viva" (Huerta Calvo, 1999: 9). La lectura del montaje de la CNTC en clave de carnaval no es desproporcionada si consideramos que por entonces "la representación teatral en su conjunto es considerada en clave de fiesta" donde se mezclan "las obras mayores con otras piezas menores en un espectáculo verbal, visual y musical, como jamás después se ha conocido en la historia teatral de Occidente" (Huerta Calvo, 1999: 9-10). John E. Varey (1987: 71-78) aborda esta cuestión en "La creación deliberada de la confusión: estudio de una diversión de carnestolendas de 1623", en cuyas páginas describe un festejo ("carnestolendas": carnaval) que se celebró en el antiguo Alcázar de Madrid el 29 de febrero de dicho año, una celebración en la que se combinaron entretenimientos varios entre los que se encuentran muchos de los bailes populares escogidos por Narros para el montaje de la CNTC. El gran despliegue de medios que ha supuesto Fiesta barroca a nivel técnico y artístico (con un vestuario que ha desempeñado un papel primordial) ${ }^{28}$, y el escenario adoptado para la ocasión (las calles de Madrid y la Plaza Mayor), evoca, claramente, el espíritu festivo del carnaval. En este sentido, Miguel Narros concibe este evento en los mismos términos que Peter Burke:

\section{El Carnaval puede verse como una inmensa obra de teatro, representada} en las calles y las plazas principales, convirtiendo a la ciudad en un inmenso escenario sin paredes, $y$ donde sus habitantes -ya fuesen actores o simples espectadores-podían observar las escenas desde sus balcones (Huerta Calvo, 1999: 9).

Andrés Peláez Martín (2000: 121) también hace referencia a la capacidad de Miguel Narros "para hacer de calles y plazas -ahora madrileñas- un tablado en el que la propia ciudad es protagonista y es su propia escenografía". Este mismo efecto (hacer de la ciudad un escenario) es también reseñado por el mismo Goethe (2014: 40) a raíz del carnaval de Roma al que asistió por primera vez en 1787: "en cada fiesta, los tapices que se cuelgan,

28 Fiesta barroca ha contado con más de trescientos trajes diseñados por Miguel Narros, sin descuidar la personalidad de cada uno de los personajes (ya fueran actores principales o figurantes). El estilo de Narros figurinista ha experimentado con todo tipo de tendencias: desde el barroquismo extremado, a la sobriedad y la depuración de líneas y colores, e incluso diseños orientales. 
las flores que se esparcen y los paños que se tienden convierten las calles, por así decirlo, en grandes salones y galerías".

Al margen de las críticas surgidas por el excesivo gasto económico que supuso el montaje de Fiesta barroca, la recepción del espectáculo fue muy positiva como se desprende de las palabras de Inmaculada Ruiz (1992: ed. el.) quien advierte que el espectáculo "arrancó los aplausos a un público que poco a poco se introducía en un universo ajeno a lo cotidiano". Se valoró la rigurosidad con que se ha reproducido el espíritu festivo del Barroco: "Todo es igual, o muy parecido, a como se hacía en el XVII. Es lo que se pretendía y se consigue", en opinión de Jerónimo López Mozo (1992: 8), hasta el punto de que se ha conseguido una "fiel reproducción del teatro total de la época". La prioridad que se ha concedido al carácter espectacular frente al contenido también es una aportación positiva, como asegura López Mozo (1992: 8), convencido "de que el espectador de hoy, como el de ayer, podrá, tal vez, desentenderse de la propuesta filosófica porque no la entiende o no la comparte, pero quedará atrapado por la magia y el aparato de este gran monumento barroco". A la vista de todos los recursos empleados, de gran riqueza iconográfica y estética, Fiesta barroca puede considerarse una de las mejores creaciones de Andrea D'Odorico.

\section{REFERENCIAS BIBLIOGRÁFICAS}

ALMELA BOIX, M. (2000). “Puestas en escena fin de siglo". Signa: Revista de la Asociación Española de Semiótica, 9, 119-154. Disponible en línea: http://www.cervantesvirtual.com/obra-visor/ signa-revista-de-la-asociacion-espanola-de-semiotica--8/html/dcd931cc-2dc6-11e2-b417000475f5bda5_25.html [01/12/2016].

ALONSO DE SANTOS, J. L. (1984). “Con Andrea D’Odorico, escenógrafo de La casa de Bernarda Alba". Primer Acto. Cuadernos de Investigación Teatral 205, 32-42.

AMESTOY, I. (2002). "Miguel Narros, en el filo del teatro". En Miguel Narros, una vida para el teatro, L. García Lorenzo y A. Peláez Martín (eds.), 13-54. Almagro: Festival de Teatro Clásico de Almagro.

ANDURA VARELA, F. (2000). “Calderón en la escena española, 1900-2000”. En Calderón en escena: siglo XX, VV. AA., 123-152. Madrid: Comunidad de Madrid, Consejería de Cultura.

BONET CORREA, A. (1986). “Arquitecturas efímeras, ornatos y máscaras. El lugar y la teatralidad de la fiesta barroca". En Teatro y Fiesta en el Barroco: España e lberoamérica, J. M. Díez Borque (ed.), 41-70. Barcelona: Ediciones del Serbal.

(1992). "Arte Barroco en el Madrid de Calderón de la Barca". En Fiesta Barroca, J. M. Díez Borque, A. Domínguez Ortiz y A. Bonet Correa, 107-120. Madrid: Instituto Nacional de las Artes Escénicas y de la Música. 


\section{OLIVIA NIETO YUSTA}

CALDERÓN DE LA BARCA, P. (1983). Entremeses, jácaras y mojigangas, Evangelina Rodríguez y Antonio Tordera (eds.). Madrid: Castalia. (2003). El gran mercado del mundo, Ana Suárez (ed.). Kassel: Reichenberger. (2006). El sacro Pernaso, Antonio Cortijo (estudio) y Alberto Rodríguez Rípodas (ed.). Kassel: Reichenberger. (2007). La torre de Babilonia, Valentida Nider (ed.). Kassel: Reichenberger.

CARRASCO, B. (1980). "Macbeth, de Shakespeare, abre la temporada del teatro Español". El País,

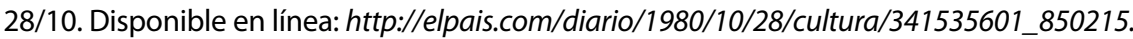
html [01/12/2016]

CORTIJO, A. (2006). “Estudio". El sacro Pernaso, Pedro Calderón de la Barca, Alberto Rodríguez Rípodas (ed.). Kassel: Reichenberger.

DAVIS, C. (2007). “Calderón en Yepes: el estreno de El mágico prodigioso (1637)". Criticón, 99, 193-215. Disponible en línea: http://pcvc.cervantes.es/literatura/criticon/PDF/099/099_193. pdf [01/12/2016].

DÍEZ BORQUE, J. M. (1992). “Fiesta sacramental barroca de El Gran Mercado del Mundo de don Pedro Calderón de la Barca". En Fiesta Barroca, J. M. Díez Borque, A. Domínguez Ortiz y A. Bonet Correa, 25-86. Madrid: Instituto Nacional de las Artes Escénicas y de la Música.

(1994). “La fiesta sacramental calderoniana en 1992”. En Hacia Calderón. Décimo Coloquio Anglogermano, Passau, 1993, H. Flasche (ed.), 55-66. Stuttgart: Steiner.

EGIDO MARTíNEZ, A. (1995). El gran teatro de Calderón: personajes, temas, escenografía. Kassel: Reichenberger.

ESCUDERO, L. y ZAFRA, R. (2003). Memorias de apariencias y otros documentos sobre los autos de Calderón de la Barca. Kassel: Reichenberger.

FERNÁNDEZ RUBIO, A. (1992). "270 actores celebrarán en la Plaza Mayor de Madrid un auto sacramental". El País Madrid, 18/06. Disponible en línea: http://elpais.com/diario/1992/06/18/ cultura/708818404_850215.html [01/12/2016].

GOETHE, J. W. (2014). El carnaval de Roma. Barcelona: Alba.

HUERTA CALVO, J. (1999). “Presentación”. En Teatro y Carnaval, J. Huerta Calvo (coord.), 9-11. Madrid: Compañía Nacional de Teatro Clásico (Cuadernos de Teatro Clásico, n. 12).

HUERTA CALVO, J.; PERAL VEGA, E. y URZÁIZ TORTAJADA, H. (2005). Teatro Español de la A la Z. Madrid: Espasa.

LADRA, D. (1985). “El castigo sin venganza”. Primer Acto. Cuadernos de Investigación Teatral 210$211,58-71$

LÓPEZ MOZO, J. (1992). “Fiesta barroca. Espectáculo para los sentidos". Reseña 232, 18.

LÓPEZ SANCHO, L. (1992). “Calderón puesto al gusto del día en la Fiesta Barroca de la Plaza Mayor". ABC Madrid, 7/07. Disponible en línea: http://hemeroteca.abc.es/nav/Navigate.exe/ hemeroteca/madrid/abc/1992/07/07/105.html [01/12/2016]. 
FIESTA BARROCA (1992): LA CIUDAD COMO ESCENARIO. UNA ESCENOGRAFÍA DE

ANDREA D'ODORICO PARA LA COMPAÑÍA NACIONAL DE TEATRO CLÁSICO

MASCARELL, P. (2014). El Siglo de Oro español en la escena pública contemporánea. La Compañía Nacional de Teatro Clásico (1986-2011). Tesis doctoral dirigida por Teresa Ferrer Valls, defendida en la Universitat de València. Disponible en línea: http://roderic.uv.es/ handle/10550/41097 [01/12/2016].

NARROS, M. (1967). "El rey Lear, en el Teatro Español". Programa de mano de El rey Lear de Shakespeare dirigido por Miguel Narros. Disponible en línea: http://teatro.es/estrenos-teatro/ rey-lear-el-7576/documentos-on-line/otros-documentos\#prettyPhoto/2/[01/12/2016].

NIDER, V. (2007). "Introducción". La torre de Babilonia, Pedro Calderón de la Barca. Kassel: Reichenberger.

NIETO YUSTA, O. (2010). "Las carceri de Darío Villalba: los encapsulados". Boletín de la Real Academia de Bellas Artes de San Fernando 110-111, 215-228.

(2016). “Tomás Marco y las artes escénicas en el siglo XXI”. En Teatro y Música en los inicios del siglo XXI, José Romera Castillo (ed.), 430-442. Madrid: Verbum.

PELÁEZ MARTíN, A. (2000). “Cien años de escenarios para Calderón”. En Calderón en escena: siglo XX, J. M. Díez Borque y A. Peláez Martín (eds.), 101-121. Madrid: Comunidad de Madrid, Consejería de Cultura. Se cita por la versión electrónica, digitalizada por la Biblioteca Virtual Miguel de Cervantes en 2001: http://www.cervantesvirtual.com/obra/cien-anos-deescenarios-para-calderon/[01/12/2016].

(2002). "Miguel Narros, figurinista". En Miguel Narros, una vida para el teatro, L. García Lorenzo y A. Peláez Martín (eds.), 55-66. Almagro: Festival de Teatro Clásico de Almagro. (2015). “Andrea D'Odorico. Los espejos del alma”. Reseña de la exposición organizada por el Museo Nacional del Teatro y celebrada entre el 2/07 y el 30/08 de 2015. Disponible en línea: $h t t p: / / m u s e o t e a t r o . m c u . e s / a n d r e a-d o d o r i c o-l o s-e s p e j o s-d e l-a l m a /[01 / 12 / 2016]$.

PERALES, L. (2014). “D'Odorico, culto, esteta, grandísimo escenógrafo". El Cultural, 5/12. Disponible en línea: $h t t p: / / w w w . e l c u l t u r a l . c o m / b l o g s / s t a n i s / a v b l o g / 2014 / 12 / d o d o r i c o-c u l t o-$ esteta-grandisimo-escenografo/ [01/12/2016].

PÉREZ, M. (1998). El teatro de la transición política (1975-1982). Recepción, crítica y edición. Kassel:

Reichenberger.

PÉREZ SIERRA, R. (1992). Fiesta barroca. Programa de mano. Madrid: Instituto Nacional de las Artes Escénicas y la Música.

RODRÍGUEZ, E. y TORDERA, A (1983). "Introducción y nota”. En Entremeses, jácaras y mojigangas, Pedro Calderón de la Barca. Madrid: Castalia.

ROSE, C. H. (1983). “¿Quién escribió la Segunda Parte de La Hija del aire? ¿Calderón o Enríquez

Gómez?". En Calderón: Actas del Congreso Internacional sobre Calderón y el Teatro Español del Siglo de Oro (Madrid, 8-13 de junio de 1981), L. García Lorenzo (coord.), 603-615. Madrid: Consejo Superior de Investigaciones Científicas.

RUIZ, I. (1992). "La Fiesta barroca trasladó Madrid hasta el siglo XVII". El País, 7/07. Disponible en línea: http://elpais.com/diario/1992/07/07/cultura/710460007_850215.htm/ [01/12/2016]. 
SUÁREZ, A. (2003). "Introducción". En El gran mercado del mundo, Pedro Calderón de la Barca. Kassel: Reichenberger.

TORRES, R. (2000). "El preciosista montaje de Narros y D'Odorico descubre un nuevo Calderón". El País, 1/10. Disponible en línea: http://elpais.com/diario/2000/10/01/ madrid/970399464_850215.html [01/12/2016].

(2012). “La Yerma sobria y austera de Narros". El País, 15/08. Disponible en línea: http:// cultura.elpais.com/cultura/2012/08/14/actualidad/1344974148_170664.htm/ [01/12/2016].

(2013). "Muere Miguel Narros, un gran referente para el teatro español". El País, 21/06. Disponible en línea: http://cultura.elpais.com/cultura/2013/06/21/ actualidad/1371803963_776790.html [01/12/2016].

VAREY, J. E. (1987). Cosmovisión y escenografía: el teatro español en el Siglo de Oro. Madrid: Castalia.

Recibido el 14 de abril de 2016.

Aceptado el 26 de octubre de 2016. 